\title{
ASO Author Reflections: The Prognostic Value of Time to Metastasis in Colorectal Liver Metastasis
}

\author{
Diederik J. Höppener, MD, and Cornelis Verhoef, MD, PhD
}

Department of Surgical Oncology and Gastrointestinal Surgery, Erasmus MC Cancer Institute, Rotterdam, The Netherlands

\section{PAST}

Within the field of colorectal cancer (CRC), especially concerning colorectal liver metastases (CRLM), time to metastasis is generally seen as an important prognostic indicator. The interval between resection of the primary malignancy and the detection of CRLM, also known as the disease-free interval (DFI), is a key element in the current clinical risk scores. ${ }^{1,2}$ A recent analysis questioned this, when no noticeable prognostic information was found for the time to metastases in patients with metastatic CRC. ${ }^{3}$ However, no distinction was made between dissemination site(s) and local, systemic, or palliative therapy. This study therefore evaluated the prognostic value of the DFI specifically in patients with CRLM eligible for surgical therapy.

\section{PRESENT}

Our results indeed show that the prognostic value of the DFI in patients eligible for surgical treatment of CRLM is more limited than previously thought. ${ }^{4}$ The DFI proved only prognostic for early disease recurrence, but this earlier disease recurrence did not seem to translate into an

ASO Author Reflections is a brief invited commentary on the article, "The Disease-Free Interval Between Resection of Primary Colorectal Malignancy and the Detection of Hepatic Metastases Predicts Disease Recurrence but Not Overall Survival," Ann Surg Oncol. 2019;26:2812-20.

(C) The Author(s) 2019

First Received: 4 October 2019;

Published Online: 23 October 2019

C. Verhoef, MD, $\mathrm{PhD}$

e-mail: c.verhoef@erasmusmc.nl impaired overall survival. While this could be due to a higher rate of salvage therapy, no correlation was found between DFI and salvageability for recurrences.

\section{FUTURE}

The results of the study show that prognosis prediction based solely on clinical variables leaves much to be desired, because the clinical variable assessed only proved of limited prognostic value. While clinical variables can sometimes be considered as a proxy for tumor biology, future efforts to improve prediction modelling should perhaps be based more on actual biological factors instead. Potential candidates within the field of CRLM include (but are not limited to) the histopathological growth patterns and the quantification of immune infiltration at the tumour microenvironment. ${ }^{5,6}$

DISCLOSURE The authors report no conflicts of interest.

OPEN ACCESS This article is distributed under the terms of the Creative Commons Attribution 4.0 International License (http://crea tivecommons.org/licenses/by/4.0/), which permits unrestricted use, distribution, and reproduction in any medium, provided you give appropriate credit to the original author(s) and the source, provide a link to the Creative Commons license, and indicate if changes were made.

\section{REFERENCES}

1. Fong Y, Fortner J, Sun RL, Brennan MF, Blumgart LH. Clinical score for predicting recurrence after hepatic resection for metastatic colorectal cancer: analysis of 1001 consecutive cases. Ann Surg. 1999;230(3):309.

2. Rees M, Tekkis PP, Welsh FK, O'Rourke T, John TG. Evaluation of long-term survival after hepatic resection for metastatic colorectal cancer: a multifactorial model of 929 patients. Ann Surg. 2008;247(1):125-35.

3. Rahbari NN, Carr PR, Jansen L, et al. Time of metastasis and outcome in colorectal cancer. Ann Surg. 2019;269(3):494-502. 
4. Höppener DJ, Nierop PMH, van Amerongen MJ, et al. The disease-free interval between resection of primary colorectal malignancy and the detection of hepatic metastases predicts disease recurrence but not overall survival. Ann Surg Oncol. 2019; 26:2812-20.

5. Galjart B, Nierop PMH, van der Stok EP, et al. Angiogenic desmoplastic histopathological growth pattern as a prognostic marker of good outcome in patients with colorectal liver metastases. Angiogenesis. 2019;22(2):355-68.
6. Van den Eynde M, Mlecnik B, Bindea G, et al. The link between the multiverse of immune microenvironments in metastases and the survival of colorectal cancer patients. Cancer Cell. 2018;34(6):1012-26 e1013.

Publisher's Note Springer Nature remains neutral with regard to jurisdictional claims in published maps and institutional affiliations. 